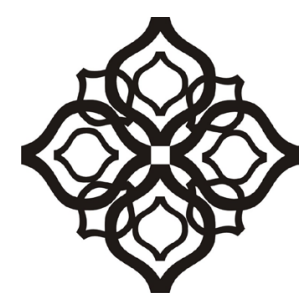

Shirkah

Journal of Economics and Business 


\section{Shirkah}

Journal of Economics and Business

Vol. 4, No. 2, May-August 2019

ISSN: 2503-4235 (p); 2503-4243 (e)

\section{Editor in Chief}

Fitri Wulandari

\section{Managing Editor}

Jasanta Peranginangin

\section{Editorial Boards}

AAbdul Azim Islahi,

Islamic Economics Institute, King Abdulaziz University, Saudi Arabia

Abu Umar Faruq Ahmad,

UBD School of Business and Economics Universiti, Brunei Darussalam

Cedomir Nestorovic,

ESSEC Business School Asia Pacific, Singapore

Johan Fischer,

Department of Social Sciences and Business Roskilde Universitetscenter, Denmark Muhamed Zulkhibri,

Islamic Research and Training Institute, Islamic Development Bank, Saudi Arabia M. Kabir Hassan,

Department of Economics and Finance, University of New Orleans, United States Musa Asy'arie,

Faculty of Islamic Economics and Business, IAIN Surakarta, Indonesia

Nunung Nurul Hidayah,

Aston Business School, Aston University, Birmingham, United Kingdom

Saim Kayadibi,

Department of Economics, Kulliyyah of Economics and Management Science,

International Islamic University Malaysia, Malaysia

Shaikh M Ghazanfar,

Departement of Economics, University of Idaho, Russian Federation 
Sigit S. Wibowo,

Department of Management, Faculty of Economics and Business, Universitas Indonesia, Indonesia

Vihang R. Errunza,

Desmarais Global Finance Research Centre, Desautels Faculty and Management, McGill University, Canada

\section{Assistant to Editor}

M. Endy Saputro

M. Zainal Anwar

Shirkah Journal of Economics and Business is a peer-reviewed journal published three times a year (January-April, May-August and September-December) by Faculty of Islamic Economics and Business, Institut Agama Islam Negeri (IAIN) Surakarta Central Java, Indonesia. The main objective of Shirkah is to offer an academic space of exchange ideas and initiate the increase number of qualified article produced by postgraduate students, practitioners and academicians.

\section{Editorial Office}

Ruang Jurnal Shirkah

Lantai Dasar, Sayap Barat, Fakultas Ekonomi dan Bisnis Islam, IAIN Surakarta

Jln. Pandawa No. 1, Kartasura, Sukoharjo, Jawa Tengah Kode Pos. 57168

Phone (+62271) 781516 Fax: (+62271)782336

E-mail: shirkahjournal@iainsurakarta.ac.id; shirkahiainsurakarta@gmail.com Website: http://shirkah.or.id/ 


\section{Shirkah}

Journal of Economics and Business

Vol. 4, No. 2, May-August 2019

ISSN: 2503-4235 (p); 2503-4243 (e)

\section{Table of Contents}

\section{Articles}

Abd Hannan

Santripreneurship and Local Wisdom Economic Creative of Pesantren Miftahul Ulum

Muh. Salahuddin

Nurhilaliati

Zaenal Arifin

Entrepreneurship and Economics of Pesantrens in Lombok Island

Abdul Jalil

Alumni Networks and Economic Reinforcement in Pesantren

Ummussabri

Jehan Maya Zayanie

Ahsana Fitria

Rosidatul Kamariah

Bank Wakaf Mikro and Creative Economics in Pesantren Buntet

Farihatul Qamariyah

Muslim Business Women in Indonesia

Fachrurazi

Dwi Srya Atmaja

Zaenuddin Hudi Prasojo

Muslim Businessmen and Chinese Economics in Singkawang 


\title{
Santripreneurship and Local Wisdom Economic Creative of Pesantren Miftahul Ulum
}

\author{
Abd Hannan \\ Institut Agama Islam Negeri (IAIN) Madura \\ hannan.taufiqi@gmail.com
}

\begin{abstract}
Madura is well-known as an island which has been identical to the values of religion. One of the values is the important role of religious institutions, such as pesantren. The role of pesantren as a traditional Islamic institution is not limited to religious areas only, but to other social aspects only, including in economic development. This study examines the economic development of pesantren through analyzing santripreneur based on local wisdom in Pamekasan, Madura, East Java, Indonesia. This study outlines descriptive-narrative explanations regarding the value of Madurese local wisdom, and creative economic santripreneur activities in the pesantren, such as batik crafts, pesantren supermarket, and sharia-based pesantren (ikhtisab) as an economic development strategy in the pesantren of Miftahul Ulum, Pamekasan. Moreover, it offers the idea of pesantren economic development in Madura, especially in the context of strengthening the economic independency and sustainability.
\end{abstract}

Keywords: Madura, santri, entrepreneurship, local wisdom

\section{Introduction}

The economic development has been one of the social issues that attract the attention of academicians, both at the theoretical and practical level. At the theoretical level, such discourses on the development provides momentum when the direction of world development faces a new 'kiblat' (direction), namely sustainable development. Whereas at the practical level, the issues of the development have been discussed as 
matters of threatening the stability of global communities, such as poverty, social inequality, and environmental pollution (Budi, 2010: 34). Various ideas for the development have emerged, which aims to solve the social problems, one of the ideas is developing local wisdom. Furthermore, the development of local wisdom is expected to be a solution, not only on reducing poverty and social inequality, but also in terms of sustainable nature.

Theoretically, the development of local wisdom has a dual vision. On one hand, building regions based on the potentials, on the other hand, it invites the participative involvement of local communities collectively (Aulia and Dharmawan, 2014: 346). For Indonesia context, the development of local wisdom contains strategic values, especially to balance certain regions that have special social typologies, such as Madura islands. The social typology of the Madurese community is identical to religious symbols and institutions (Hidayati, 2009: 66), pesantren can be a strategic value to be used as instruments to develop local region.

For the government, the idea of strengthening economy through the creative economy of pesantren is a fairly logic consideration. This is due to the fact that the number of pesantren in Indonesia (for an example in 2019) reaching 27,290 institutions, with 3.65 million santris (Ministry of Industry, 2015). Presumably, several regions that have been known as the basic existence of pesantrens, such as Madura, can cover strategic value as a role model for regional economic development. The strategic value lies in the pesantren's identity has a strong traditional value and a broader social network (Bawono, 2018: 39). This fact can be a plus value for the existence and economic sustainability of pesantren, strengthening not the local economy only, but also on a larger national scale.

Much have been written on pesantren and creative economy, known as santripreneur, which attempts to trace the dynamics of 
santripreneur of pesantren. Such research is Siti Afidah (2018), who analyzes on santripreneurship of pesantren Tegalrejo in Magelang (2018). Afidah discovers the fact that the economy in the pesantren in Tegalrejo run its management independently through the santripreneurship strategy. In its implementation, santripreneurship in the pesantren has been implemented in three (3) steps, namely observation, monitoring, and workshops. These three steps are fully implemented to the santri community, whose aims to foster the spirit of santripreneurship so that in the end they have personal skills (Afidah, 2018: 147). Another study come from Maksum and Wajdi who (2018: 226) find the fact that the independence of pesantren in the economic sector lies in their learning instruments which are attached to santripreneur. Santripreneur education here has been formed through pesantren learning activities which oriented to holding economic independence, raising creativity, and strengthening religious character.

This study examines the economic development of sustainable pesantrens through engaging santripreneur based on local wisdom. There are three main problems that discussed here, namely; the concept of santripreneur, referring to creative economic actors in the pesantren community, such as santri, kyai, and communities in the pesantren; and the concept of local wisdom, denoting to all natural-social potential that characterizes the local area. What does it mean by the concept of local wisdom? How does the concept of developing local wisdom-based santripreneur run in the Miftahul Ulum? How does the development of santripreneur play a strategic role in strengthening the economy of the pesantren? The data of this research has been gathered through doing interview and observation in the pesantren of Miftahul Ulum. This study contributes to enrich the field of contemporary socio-economics and especially offering the practical example of pesantren values to develop sustainable economics in Madura. 


\section{Defining Local Wisdom}

In social scientific discourse, the term "local wisdom value" is not a new term. This term often appears within the discourse of development and locality. It is situated as a cultural, sociological, political, educational or economic sphere. This concept has been increasingly popular after many countries introduce it as marketing strategy for regional development. In terms of terminology, the value of local wisdom refers to various naturalsocial wealth growing in a community that is recognized as important elements to strengthening social cohesion among the community (Abdullah, 2008: 7). This definition implies that the value of local wisdom has developed from the creativity of the community, which has been internalized in their daily awareness, thoughts, attitudes, and behavior. The concept of social cohesion requires the function and strategic role of local wisdom as a form of community which lead to integrity and unity.

The term local wisdom comes from a system of knowledge which empowers local values, traditions, and customs (Aulia and Dharmawan, 2014: 346). The concept of local wisdom can be understood as knowledge of culture that being exists in certain social systems and structures of society which includes a series of cultural knowledge consisting of a cultural knowledge, as well as procedures for management, empowerment, and sustainable use of natural-social resources (Arafah, 2002: 231). Wisdom contains an overview of the opinions of the people concerned about matters relating to the structure of the environment, environmental functions, natural reactions to human actions, and relationships that should be created between humans (society) and their natural environment (Aulia and Dharmawan, 2014: 346).

The value of local wisdom has been defined as knowledge, ideas, values, skills, experiences, behaviors, and customary habits carried out by communities in certain regions (Hayati, 2016: 40). Therefore, local 
wisdom is part of the reality of the community that has a complexity of values, within certain constraints, functioning as a strategy and a view of life to answer various problems in an effort to meet the needs of the local community. Regarding the function of the value of local local wisdom above, Sartini (2004) states that local wisdom consisting of culture, tradition, knowledge, creation, and a set of other local values which has a function as conservation and preservation of regional natural-social resources, development of human resources, development of culture and science, and preservation of beliefs, literature and taboos (Sartini, 2004: 127).

\section{Local Wisdom and Pesantren}

Such local wisdom in Pamekasan represents the social reality of Madurese people, since it refers to every knowledge, idea, value, skill, experience and habits that carried out by communities in certain regions. The value of local wisdom in this sub-discussion is not merely about the form of Pamekasan culture but also concerning the potential of the social reality. Culture as a tangible manifestation of the value of local wisdom covers a very broad aspect. Culture is not merely about manifestation of creativity, art, work, tradition, or custom. More than that, culture also includes the paradigm of thinking, science, social systems, and governance of people's lives. Therefore, talking about Madurese culture, it will directly lead us to a discussion about the life of the Madurese community. The value of local wisdom and culture is an inseparable unit.

The local wisdom of the Madurese community may actually be divided into three major groups. First, socio-cultural aspect of local wisdom, which has been living within systems of culture such as sapeh sonok, sapeh kerrap, tari pecut, rokat tase', remoh, tanian lanjheng and solidarity (Jafar, 2017: 119). Second, social economic aspect of Madurese local wisdom's 
value which rests on natural-social resources, such as salt farming, fish ponds, and tobacco. Economic potentials such as Madura batik are also one of the values of local wisdom that has boasted local economics. Third, social religious capital which has generally existed in Madurese daily life (Susanto, 2007: 97). Religiosity is the construction of local values which presupposes respect, recognition, and symbols. Religious symbols such as the existence of pesantren become a local social structure that plays a strategic role in the overall social aspects, including within the economic sector of the Madurese community in general.

In general, it can be ascertained that the portrait of the socioreligious structure of the Pamekasan area are generally almost the same as the culture of other Madurese communities, such as Sumenep, Bangkalan, and Sampang. Social religious values as a distinctive Madurese identity are embedded in many Pamekasan cultural products. Moreover, as is known, Pamekasan itself is an area that has a strong nuance of religiosity, which has a big influence on the social construction of the local community. Sociologically, the community's religiosity is clearly illustrated by their attitudes and admiration for religious symbols. In this connection, religious symbols such as the religious organization Nahdhatul Ulama '(NU), kyai, and pesantren have been social structures that are not only influential, but also have strategic roles and functions.

Regarding the existence of pesantren, it must be admitted that its existence has become one of the most important social institutions in the social structure of the local community. It is due to the fact that pesantren are traditional social-religious institutions that have a large role in social sustainability in all life spheres. Pesantren are not merely institutions that have a function as a place for the teaching and learning process. More than that, pesantren has been a collection of systems, values, norms, and social institutions in which there has been a variety of life views that are used as 
guidelines for many communities. The ability of pesantren to accommodate people is a proof, that this institution has strong social capital to mobilize the community in forming and maintaining certain social realities. For this reason, in the context of the social life of Pamekasan society, pesantrens play an important role in transforming Islamic values and shape cultural and social values. This condition is in turn by many social academics, pesantren has functioned as a cultural broker (Farid, 2007: 238).

The strong influence of pesantrens in Pamekasan society has been equivalent by the number of pesantrens in Pamekasan Regency. Quantitatively, it is assured that the existence of pesantrens is widespread throughout the sub-district of Pamekasan without exception. Starting from the city sub-district, especially at the district level which has a village, suburban and inland typology. In regard to numbers as well as maps of the spread of pesantrens in Pamekasan, it can be seen in the following table:

Table 1. Number of Pesantrens at Pamekasan District Regency 2018

\begin{tabular}{|c|l|c|c|}
\hline No & Kecamatan & Number of Pesantren & Number of Santri \\
\hline 1 & Tlanakan & 11 & 2,109 \\
\hline 2 & Pademawu & 5 & 688 \\
\hline 3 & Galis & 2 & 93 \\
\hline 4 & Larangan & 19 & 3,625 \\
\hline 5 & Pamekasan & 11 & 4,394 \\
\hline 6 & Proppo & 10 & 5,54 \\
\hline 7 & Palengaan & 29 & 25,012 \\
\hline 8 & Pegantenan & 24 & 2,422 \\
\hline 9 & Kadur & 20 & 5,585 \\
\hline 10 & Pakong & 11 & 3,481 \\
\hline 11 & Waru & 8 & 2,353 \\
\hline 12 & Batu Marmar & 19 & 3,274 \\
\hline 13 & Pasean & 16 & 1,233 \\
\hline & & 185 & 59,323 \\
\hline
\end{tabular}

Source: Office of the Department of Religion of Pamekasan Regency 
In general, the number of pesantren above can be divided into two major groups, namely pesantrens with salaf systems, and pesantren with khalaf systems (Abdullah, 2007: 15). Salafpesantren refers to a characteristic of pesantrens that have implemented traditional systems of learning. The traditional concept here denotes to the whole system of education and teaching that has been applied in the pesantren. It also signifies to the pesantrens which hold strong religious rites of classical Islam. On the contrary, the khalaf pesantren is a characteristic of pesantren that open to the modern educational system, or at least to combine both, between modern and traditional. Regarding to the pesantren's roles and functions in Pamekasan, it outlines as narrated by KH Misbah (2019), the leader of the Miftahul Ulum Pesantren.

First, similar to pesantren in general, religious function has been the main role of the existence of pesantren in Pamekasan. This is the pesantren identity which has been attached in its teachings and learning. In most pesantrens in Pamekasan, such matters concerning religion have become very principle. Relating to the religious function of the pesantren, it is said, "Oh, yes, religion is learning. The main mission of each pesantren is da'wa, learning about Islam. Then so that the community understands what religion is, it needs to be socialized, what earth is it halal is haram, not by simply saying halal haram." However, although most pesantren in Pamekasan emphasize in religion lesson, it does not nullify formal education curriculum learning. Some pesantrens have been able to take innovative steps, combining religious teaching material and formal ones. Along with this approach, pesantren strives to implement the education emancipation agenda, and leaves the tradition of educational dichotomy as it did in the past.

Second, the function of education is arguably a vital function in the pesantren. This fact is based on the role of the pesantren which in practice is 
more engaged in teaching activities than other social activities. In general, the function of pesantren education is carried out in various forms and variations. Starting from formal education activities, informal activities, and non-formal activities. At the level of formal education, pesantren hold tiered teaching and learning activities as well as formal education institutions in general. While at the level of non-formal education, pesantren organizes traditional learning systems focusing on the study of kitab kuning. In some salafi pesantrens, non-formal learning activities are carried out in the form of soroghan. As for the informal level, pesantren education activities are generally carried out collectively involving the entire pesantren community, both from the kyai, santri, and the community around the pesantren. Whereas for the khalaf pesantren, they have implemented a modern system, for an example of the Miftahul Ulum Pesantren, the education system has been implemented by accommodating two different education systems, between formal and non-formal education. To be able to answer the complex social changes, pesantren are required to be able to accommodate the educational needs of the community in all forms of cross-scientific matters.

Third, the function of culture presupposes all forms of religious ritual activities that shows characteristic of pesantrens, such as tablilan, shalawatan, hadarah, banjari, and so forth. Interestingly, the function of the pesantren culture is not merely aimed at the meaning of culture, but also as a religious representation that reflects the values of religiosity. Consequently, the majority of pesantrens have inclusive attitudes and behaviors towards all forms of local culture in the vicinity, without losing their identities as religious institutions. At the level of practice, the pesantren's cultural function is manifested in the form of values, where religious moral messages are not only represented by taught, but also transformed in the form of religious ritual activities that are in direct contact with local community 
values and creativity, such as traditions, customs, and arts. To sum up, the function of culture in the Pamekasan Pesantren, especially at the Miftahul Ulum Pesantren, are in the form of koloman, and hadrah.

Fourth, economic function has been one of the functions that rarely known. In general, most people consider the role and social function of pesantrenis limited to strengthening and developing religious matters and education. In fact, pesantrens, as one of the traditional religious institutions that coexist directly with grassroots communities, have great potential to advance and develop surrounding life activities; not only in the field of education, but also in the most substantial aspects that are in direct contact with the economy and welfare of the umma. In this aspect, pesantren through their ability to adapt to local communities, can play a strategic role as the economic wheel of the umma. This strategic role can be carried out in the form of economic activities that are oriented to strengthening of the value of local wisdom, the establishment of cooperatives, the provision of sharia-based savings and loan services, and the development of popular businesses in the form of creative economics. One of them is through creating santripreneur activities. This economic activity was a concern in several pesantrens in Pamekasan, one of which is in the Miftahul Ulum Pesantren, as clearly illustrated by KH. Misbah (2019), “... on the second generation, under the leadership of KH. H. Mu'afa, pesantren are not only involved in social problems, but are also involved in pioneering and advancing the economy of the pesantren."

Relating to the creative economic function happened in surrounding pesantren in Pamekasan, the model of economic development in Pesantrens has been designed in the form of commerce and provision of savings and loan services. In terms of commerce, the economic role of pesantren has mostly been built in term of retail economies such as shops and supermarkets. As for savings and loan services, it has been popular 
as sharia cooperation called Baitul Wat Tamwill (BMT), which is in the Miftahul Ulum Pesantren called Al-Iktisab, a large four-unit supermarket that is widespread in four different villages. BMT al-Iktisab, a savings and loan service as well as investment, amounted to six (6) branches that were widespread in five different sub-districts. In addition to these two economic activities, the Miftahul Ulum Pesantren has practiced the creativity of santri such as batik crafts, cooking, gambus music and albanjari. These last two, although only in the form of art, but have proven to help drive the economy of the pesantren.

\section{Santripreneur of the Miftahul Ulum}

Miftahul Ulum Pesantren is located right in Kacok Village, Palengaan District, Pamekasan Regency. It was established in 1978, while now has passed three generations of leadership, namely KH. Asy'ari (19781991), KH. Muafa Asy'ari (1991-2012), and KH. Misbahul Munir Asy'ari (2012-present). Similar to other pesantrens in general, the Miftahul Ulum Pesantren has unique character, especially regarding the social orientation of pesantren education which focuses on religious education (Islam). The pesantren has functioned to create, maintain and develop Islamic values in Pamekasan Regency and in the community of Palengaan District in particular.

However, although Miftahul Ulum has prioritized religion, it does not make itself indifferent to social change. In this context, Miftahul Ulum has a principle that pesantren must be able to answer the current global challenges. Pesantren as a central education institution in Pamekasan are expected not only to answer religious issues. Pesantren must be a problemsolver to the challenges and social problems that arise in today's global era. Therefore, for the Miftahul Ulum, pesantren must now revolutionize themselves like a "super market", which philosophically implies that 
pesantren must be able to provide solutions to the overall problem of society, especially concerning their stability and sustainability. This includes concerns about economic problems and people's welfare.

In order to achieve those goals, Miftahul Ulum in turn has applied a universal pesantren education model, which does not only focus towards religious issues, but also in the economic sectors. The economic management of Miftahul Ulum has been developed in many approaches. Broadly speaking, there are at least five main economic activities in the Miftahul Ulum, namely sharia-based investment activities in the form of Baitul Wat Tamwil (BMT) Al-Iktisab, a supermarket in the form of pesantren cooperation (kopontren) Al- Iktisab, a creative economy in the form of batik crafts, Alik studio photo, and finally the Alik Motor automotive workshop. In general, the five economic activities of the pesantren run on the principles of the santri by the santri and for the santri. In other words, all economic activities in the Miftahul Ulum are absolutely based on the existence of santri, whether for the economic capital, the management and the marketing. Santri is the main pillar of sustainability and the goal of pesantren developing economy.

Baitul wat Tamwil (BMT) Al-Iktisab. Institutionally, KSPPS BMT al-Iktisab Miftahul Ulum has been established in 2014. It obtained a legal entity in the same year, through legal provisions 04/ BH/ XVI.19/ 2016. Two years later, in 2016, the KSPPS BMT al-Iktisab Miftahul Ulum was changed with a number; 34 / PAD / BH / XVI.19 / 16, issued directly by the Pamekasan Regency Cooperative Office. For the five-year establishment, KSPPS BMT al-Iktisab Miftahul Ulum has been noted to have 486 members, of which all members were divided into two large sections, namely ordinary members and extraordinary members. KSPPS BMT alIktisab Miftahul has had six (6) branches spread in four sub-districts of Pamekasan Regency, namely Palengaan District, Kec. Pagentenan, Kec. 
Pakong, and Kec. Tlanakan. In the economic development sector, KSPPS BMT al-Iktisab is arguably being the economic anchor of the pesantren. In 2017, KSPPS BMT al-Iktisab Miftahul was recorded as successful in helping the economic development of Pesantrens, by donating maslahah funds in the amount of Rp. 200,274,334. In 2018, the amount of funds maslahah from KSPPS BMT al-Iktisab Miftahul experienced a significant increase, reaching to Rp. 475 . 678,356.

Table 2. BMT al-Ikhtisab in 2018

\begin{tabular}{|c|c|c|c|c|}
\hline \multirow{2}{*}{ No } & \multirow{2}{*}{ Information } & \multirow{2}{*}{ Total Number } & \multicolumn{2}{|c|}{ Growth } \\
\cline { 4 - 5 } & & & Total Number & Percentage \\
\hline 1 & Office & 6 & 2 & $1.3 \%$ \\
\hline 2 & Employee & 39 & 8 & $1.3 \%$ \\
\hline 3 & Member & 486 & 27 & $1.1 \%$ \\
\hline 4 & Depositor & 4.773 & 227 & $1.1 \%$ \\
\hline 5 & Borrower & - & - & - \\
\hline
\end{tabular}

Source: Head of the al-Ikhtisab Cooperative Miftahul Ulum Pamekasan

Besides being able to donate funds to the pesantren, the BMT KSPPS al-Iktisab Miftahul has also played a major role in absorbing workers, especially for the local pesantren community. Of the six branches, KSPPS BMT al-Iktisab Miftahul has recorded as many as 39 employees, all of whom have a background as part of the pesantren community, such as santri, pesantren alumni, and communities in the pesantren. Based on the recognition of students who work as employees at KSPPS BMT al-Iktisab, their income can be sufficient to help meet family needs. The nominal salary they can vary from the lowest nominal Rp. 750,000 to the highest salary nominal Rp. 1,250,000 (interview with Mulyadi, 2019).

Al-Iktisab Kopontren supermarket, commonly referred by santri and surrounding community under the name Koperasi Pondhuk (read: Pesantren Cooperation), can be regarded as the most powerful pillar and 
the main support for pesantren economy. Even though it is in the form of a supermarket, the economic building of the Kopontren Al-Iktisab Supermarket is anchored in other sectors, even compared to the KSPPS BMT al-Iktisab though. If the role and function of KSPPS BMT al-Iktisab is only on the aspect of physical development of pesantren alone, then it is different with the Kopontren Al-Iktisab Supermarket, where its existence is the backbone of the entire pesantren needs. Both the physical development aspects of the pesantren, and the overall funding of the pesantren education which is related to the continuity of teaching and learning activities, such as the provision of school facilities, as well as intensive or salary of teaching staff. Based on the information from the informant, for the teacher's monthly salary alone, Al-Iktisab Kopontren Supermarket paid no less than Rp. 24,000,000. The funds are disbursed to cover teachers' salary needs at all levels of education, both formal and informal education (interview with Salam, 2019).

Since 2009, Al-Iktisab Kopontren Supermarket has been growing rapidly. In terms of quantity, Al-Iktisab Kopontren Supermarket has seven branches spread over four sub-districts, namely in Pelangaan District, Kec. Pakong, Kec. Karampenang, and Kec. Pagentenan. This number has increased from previous years, which in 2018 still has five branches. Broadly speaking, the whole seven of these branches can be grouped into two, namely central kopontren and branch. Central kopontren supermarkets located right at the Miftahul Ulum, which is also being a center for selling products, such as batik and others.

Since being established in 2009, Miftahul Ulum Pesantren Supermarket has accommodated a large number of workers. There were recorded as 93 employees works there. Interestingly, the majority of employees are dominated by the Miftahul Ulum Pesantren community, both from the santri, alumni, and people living around the pesantren. In 
connection with this, based on the data in the field, Kopontren Supermarkets claimed to deliberately prioritize the Miftahul Ulum Pesantren community itself. This is based on family considerations and ties as alumni. Those who are registered as santri or alumni are more likely to have strong loyalty than those outside the Miftahul Ulum pesantren community themselves.

Crafts; if the Miftahul Pesantren Kopontren Supermarkets and KSPPS BMT al-Iktisab are considered as two major pillars of the pesantren's economy, the creative economy of batik can be regarded as a complement to the pesantren's economy. In its management, the creative economy as a whole has been driven by students. Those who are engaged in the handicraft sector in pesantren communities are women. To maintain the sustainability of the batik creative economy in the Miftahul Ulum, the pesantren held a special activity unit synergized with school activities. Although the development is not as big as other sectors, until now, the creative economy of batik crafts in the Miftahul Ulum has survived. In terms of marketing, the overall results of batik craft at the Miftahul Ulum are marketed through pesantrens spread across many regions. Based on the informant's explanation, batik craft here is the inheritance of the founders of the pesantren which has been going on for generations. Therefore, even though the existence of batik crafts in the Miftahul Ulum did not develop rapidly, even running statically, the pesantren continued to maintain it, because it was the inheritance of the previous pesantren founders, namely Nyai Nur Awaliyah (interview with Ustadzah Halimah, 2019).

Alik Studio; one of the creative economics of the Miftahul Ulum which until now has become one of the places where the creativity of the santri is photo and film studies. Alik Studio has been established since 2016. The name Al-ik studio is an acronym for the word Al-Iktisab. This means that it can be said that Alik Studio is a subsidiary of the Al-Iktisab Kopontren Supermarket, where the capital funds are directly injected by the finance of the Al-Iktisab Kopontren (interview with Idris). 
In the beginning, Alik Studio was established only to provide santri who needed photo setting or printing services. As the time flies, the pesantren in turn has expanded the photo study business into film studies. Nowadays, Alik Studio has grown rapidly, it has even become one of the famous photo and film studios in Pamekasan. Alik Study photo has been led by Ust. Mulyadi Wijaya, senior pesantren administrator. Overall, Alik Studi photo accommodates five employees. Every week, Alik Studi never missed covering, even at certain moments, such as the wedding months, they were overwhelmed to serve requests (interview with Idris, 2019).

Alik Motor; the last creative economic sector that has been operating in the Miftahul Ulum is an automotive workshop. Similar to Alik Studio, Alik Motor stands for Al-Iktisab, which suggests that Alik Motor itself is a manifestation of the economic expansion of Al-Iktisab Kopontren Supermarket, especially in the automotive sector. Alik Motor itself was only established in 2017, and in the two years of its establishment, Alik Motor itself has now developed into two branches, spread in two subdistricts, namely Kec. Palengaan and Kec. Pagentenan. The management of Alik Motor is also driven by the Miftahul Ulum boarding community. There are six employees working at Alik Motor, where all of them have a background as students and alumni of the Miftahul Ulum Pesantren.

\section{Santripreneur Creative Strategy}

The Miftahul Ulum has been classified as an attractive Pesantren. At the very least, there are two reason why Miftahul Ulum has an interesting side; first, based on the number of students, the Miftahul Ulum was recorded as a relatively small pesantren with a minimal number of students compared to other pesantren, the Banyuanyar Pesantren or the Pesantren Bato, for example. Data in 2019 shows that the number of Miftahul Ulum Pesantrens is 976 students. 327 consisted of male students, and 
the remaining 649 are female students. Second, although Miftahul Ulum Pesantren has a small number of santri, they have a very significant level of economic progress. Even their supermarkets, Kopontren Al-Iktisab, known as the biggest pesantren supermarket in Pamekasan, can even compete with supermarkets outside the pesantren.

The success of the santripreneur program in the Miftahul Ulum is actually inseparable from the pesantren's economic development strategy which emphasizes the strengthening and utilization of human resources, in this case the pesantren community, such as santri, alumni, and the community in the pesantren. In terms of human resource development, the Miftahul Ulum applies an integral education system, integrates science and technology such as information technology, and masters the value faith and piety (Imtaq/ Iman Taqwa) at the same time. Therefore, every student who studies in the Miftahul Ulum does not only become a person who is careful with Mecca, but also a student who is personal to German brain skills. The mastery of science and technology and Imtaq leads to four characters of santri, STAF, namely shiddiq (honest), amanah (trusted), tabligh (transparent), and fatonah (professional). These four characters become the strategy of developing santripreneur in the Miftahul Ulum Pesantren, which deals with values and leadership.

In relation to the development of santripreneur in Miftahul Ulum, it applies several programs or activities which are grouped into two, namely theoretical and practical. In the theoretical sector, santri is equipped with a scientific system and learning that is of a universal technical nature, not only focusing on the religious field, but also provided with special insight into science and technology. To support capabilities in this field, the pesantren applies a formal education system in the form of tiered public schools. One of them is the level of vocational school education (SMK). Through the existence of this vocational school (SMK), the santri 
enterpreneur program in the Miftahul Ulum Pesantren found its space.

As for the practice area, santripreneur in the Miftahul Ulum run through pesantren activities oriented to the development of skills. At this stage, every santri has the opportunity to be directly involved in the economic activities of pesantren in the form of service (read: internship). This service lasted for two years, in which every santri has been placed in various sectors of the pesantren's economic activities, either at Kopontren Al-Iktisab, KSPPS BMT al-Iktisab, Alik Motor, or Alik Studio. In addition to internships, santri also received special training, holding creative economic workshops. On several occasions, the pesantren also conducted comparative studies on the economic governance of pesantren, especially with various other more advanced and developing pesantren, such as the Sidogiri Pesantren, Pasuruan.

Until this year, the economic development management committee of Miftahul Ulum Pesantren has conducted two (2) comparative studies, namely in 2016 and 2018. The instrument for the development of BMP al-Iktisab KSPPS in Miftahul Ulum Pesantren has been modified from BMT Sidogiri. BMT Sidogiri and KSPPS BMT al-Iktisab often involved in cooperation, such as training and skill development of employees. According to Ali Wafa (2019), as senior management and supervisor of KSPPS BMT al-Iktisab, the relationship between Miftahul Ulum and Sidogiri was driven by the strong desire of pesantren careers who wanted to become the Miftahul Ulum Pesantren as a miniature Sidogiri on Madura Island, both in terms of the development of education and the economy of pesantren.

\section{Networks and Development}

Talking about the pesantren's economic network will certainly not be complete if it does not discuss the existence of the pesantren community 
itself, namely the pesantren leaders, santri, and pesantren alumni. Pesantren leaders refer to the kyai of the pesantren, the santri are those who study at the pesantren, whether they are settled or not, and the alumni refer to the people who studied at the local pesantren. These three elements are important elements that have a strategic role and function in shaping pesantren economic networks. As mentioned earlier, economic activity in the Miftahul Ulum Pesantren is based on the principle of "santri by santri and for santri". That every pesantren's economic activities absolutely rely on the existence of santri. Santri as the spearhead, santri as managers, and their usefulness also lead to santri. Broadly speaking, the roles and functions of strategic students in the economic network of the Miftahul Ulum can be seen in capital and managers.

In terms of capital, the economic commission of the Miftahul Ulum provides a special space for santri and alumni who want to invest their shares in the development of pesantren, which in this case form KSPPS BMT al-Iktisab. For students who still live in Pesantrens, every santri is obliged to have a BMT al-Iktisab savings book, where they have the obligation to save once a week, at least Rp. 5,000. As for alumni, they are not required to open savings, but the pesantren come to each alumnus to join and take advantage of the existence of KSPPS BMT al-Iktisab. Both as members, savers, or borrowers. For the management, economic activities in the Miftahul Ulum rely entirely on the presence of santri and alumni. In general, those whom still in the status of santri have been joined the internship program. As for the alumni, they are appointed as permanent employees. With such a governance system, pesantren directly has helped society in creating jobs, especially for santri, alumni, and community in pesantren.

Economic networks in the context of developing santripreneur in the Miftahul Ulum run systematically and structurally, both theoretically and practically, both from the central level and the branch level in the 
field, for example, there are alumni organizations in the IASBA (Alumni Association of the New Santri Alumni Association). This organization is the main media for the gathering of the Miftahul Ulum Pesantren alumni, both from the central, regional, and branch levels. This organization has a strong influence in shaping and maintaining the pesantren's economic network, conditioning alumni through meeting activities at all levels. In each year, the pesantren hold a grand rally event, an event where alumni gather in all regions. In addition to this annual event, there are also monthly to weekly events, carried out by alumni associations at the branch and branch levels through established management.

\section{A Critical Analysis}

Genealogically, the word santripreneur is basically an acronym of two (2) words, namely santri and entrepreneur. Santri refers to the existence of a community of students in pesantrens, while entrepreneurs have meaning as entrepreneurs (Ministry of Industry, 2015). Thus, based on its etymological understanding, santripreneur is a santri who has two abilities at once, namely the ability of religion on the one hand, and entrepreneurial spirit on the other. In terms of terminology, santripreneur is an economic development idea in order to develop small and medium industries (SMIs) in pesantren aimed at building a national-regional industrial independence based on sharia economics. Through santripreneur activities, pesantrens which have been regarded as traditional religious institutions which are merely engaged in religion and teaching, at certain limits can be increased in level and its role in a more central stage and position, so that it is possible to answer all forms of problems social economy and the challenges of the global economy, especially regarding the agenda of sustainable economic development. 
The concept of santripreneur as a student having an entrepreneurial spirit actually has a strong relevance to the reality of pesantren in Pamekasan, in this case the Miftahul Ulum Pesantren. Although the Miftahul Ulum Pesantren has a big vision in terms of religion, which is to carry out the Islamic learning and da'wa agenda, in certain parts they also pay considerable attention to social reinforcement concerning the welfare of society in general. The magnitude of the pesantren's attention to the socio-economic aspects of the community is clearly reflected in the overall daily activities and programs of the pesantren, which not only focus on scientific aspects, but also the development and strengthening of the economic sector (interview with KH. Misbah, 2019).

At the theoretical level, the santripreneur agenda in the Miftahul Ulum Pesantren is carried out through teaching activities, courses and coaching. At this stage, students are provided with a variety of theoretical knowledge about the business world. Material and learning about the world of entrepreneurship, such as the introduction of commodities, production systems, product branding, and marketing strategies, are all theoretical learning that has been run by the pesantren. To optimize this activity, the Miftahul Ulum is based on applying cross-departmental vocational education (SMK) levels. This aims to support the skills, abilities, and skills of the santri, so that students are expected to be not only competent in scientific matters (religion), but also have skills and skills. To anticipate that vocational services are offered to be relevant to environmental needs, vocational formulations are directed at strengthening local values, such as vocational cooking, fashion, and computer science. If it is associated with the regional development strategy, the development of the santripreneur creative economy through the theoretical path of the education sector is actually a necessity. Due to one of the absolute requirements for the success of marketing and regional development must absolutely be balanced by 
the availability of talents, which in this case is closely related to human resources (Leksono, 2014: 2).

While at the practical level, the santripreneur agenda in the Miftahul Ulum is carried out in various forms of economic activities, especially those that come in direct contact with the world of entrepreneurship and business. Based on the results of researchers' data searches in the field, there are at least five types of entrepreneurship which have been the main wheels of pesantren's economy, namely large supermarkets, Alik Studio, Alik Motor, and most recently the sharia cooperative, BMT al-Ikhtisab, and savings and loan services. Through three economic activities, the santripreneur program is carried out, where every santri will have the opportunity to sharpen and explore skills to become business people and entrepreneurs in the pesantren environment that are ready to use. In addition to the three business units and businesses mentioned above, the santripreneur agenda in the practical dimension is also carried out through creative economic efforts in the form of batik and cooking.

Interestingly, both the creative economy of the batik and the culinary system were compared specifically by carrying out or highlighting the local creativity. In terms of batik, the motif that is highlighted is the typical Pamekasan batik motif that has bright color patterns, such as wood fiber batik and stone fiber batik. While in terms of cooking, creative economic products are in the form of traditional snacks and cakes which are the hallmark of Pamekasan food, such as kue bangkit, krupuk singkong, kurup pisang, and many others. In the perspective of development, utilization and strengthening of the local economy through batik, fashion, and cooking, as applied in the Miftahul Ulum Pesantren, the realization of the strategy of development and sustainable regional economic strengthening through the wisdom of the local community.

Regarding regional development strategy that has been discussed, Richard Florida (1957) mentions three (3) important points that need 
to be considered, their relation to regional development, two of which are the availability of talents and technology. Talent aspect requires that a regional economic development will succeed and will be balanced by the availability of human resource assets that are not only good, but also competitive. In the large Indonesian dictionary, talents have a sense of meaning with talent which means the basis of intelligence and abilities that are taken from birth. As for terminology, Lucy (2009) provides an explanation that talent is a potential that must be stimulated first so that it can be seen as a skill, knowledge and special abilities that can make individuals skilled and competitive. The relation to santripreneur in the Miftahul Ulum Pesantren refers to the attention of the pesantren to the existence of human resources, especially among santri. In this connection, pesantren try to stimulate and encourage the creativity of santri through the provision of universal education. At the level of practice, the formation and strengthening of talents for santri in the Miftahul Ulum Pesantren are carried out in the form of activities that are in direct contact with commercial activities, crafts, skills, arts, coaching and training. Some of them are holding creative economic workshops, conducting comparative studies, and so on.

In addition to talent aspects, another thing according to Florida that needs to be considered is the technology aspect. In the context of regional economic development, technological aspects indicate that to create economic development that is competitive and sustainable, it is necessary to have the availability of supporting facilities. Especially the use of appropriate contemporary technology that is oriented to regional needs and interests. In regard to this study, technological aspects refer to the availability and use of technology as a medium to accelerate the course of creative economic activities within the Miftahul Ulum Pesantren. At the practical level, the technological aspects here are clearly illustrated in 
the agenda of modernizing pesantren economic activities, all of which are centered on the use and ability of computerized devices, such as those applied in the KSPPS BMT al-Iktisab economic sector and Al-Iktisab Kopontren supermarket.

If all findings above being analyzed deeply, especially from point of view economic development, we will find an interesting proposition, that has been applied by the Miftahul Ulum Pesantren community. It is related to the model of local pesantren economic development. embodiment of contemporary economic development which underlies the local artifical approach. This is based on the definition, that local wisdom is the whole value of creation or view that contains elements of wisdom and civilization that take place, exist, or apply in a particular.

There are two main reasons that can justify the above proposition; First, definitively, local wisdom has been understood as a road map for economic activities that focuses on local community participation. One of the main principles of local wisdom is the participation of local people in the process of economic development, so that with such participation there is a great opportunity to raise the economic level of the community. At its peak, community participation can be an instrument to realize the welfare of the community, in this case the pesantren community such as santri, and of course the people who live in the pesantren environment. The fact that the overall economic activities of santripreneur in the Miftahul Ulum Pesantren, which have significantly helped empower the surrounding community, especially among the santri and pesantren alumni, are representations of the implementation of the local wisdom economy. This is directly proportional to the function of the value of local local wisdom, where one of them is the development of local human resources (Sartini, 2004: 127). 
Second, economic development with local wisdom includes the principles of conservation or local natural-social empowerment (Sartini, 2004: 127). This principle requires that economic development with local wisdom not only has the aim of strengthening the economy, but also being oriented towards the utilization and empowerment of the region's natural social values. In the context of santripreneur economic activities in the Miftahul Ulum Pesantren, efforts to empower and utilize the natural social values of the region are clearly reflected in the pesantren's economic instruments or approaches which tend to prioritize the values of the pesantren. As we know, pesantren has so far been known as educational institutions that are thick with Islamic scents. The use of a sharia-based economic system, as applied in the KSTPS BMT al-Iktisab sector, is a concrete manifestation of pesantren to consistently empower the pesantren's unique values, namely as a center of learning and Islamic teachings.

\section{Conclusion}

The economic development of pesantren through santriprenuer activities based on local wisdom in the Miftahul Ulum Pesantren, is basically a model of economic activity that focuses on developing and managing local wisdom values. The concept of local wisdom in the development of santriprenuer in the Miftahul Ulum requires two things; first, referring to all natural-social potential in the pesantren environment, both the potential in the form of culture, self-creativity, and all other forms of social values that grow rooted in pesantren's identity and culture; second, local wisdom requires the pattern of economic activity in the Miftahul Ulum Pesantren not only aims at strengthening the economy, but also on environmental empowerment, direct community participation, especially for the local pesantren community. 
The establishment and development of economic activities in pesantren through santriprenuer creative in the Miftahul Ulum, are generally carried out through two approaches; first, theoretical approach, this approach presupposes cognitive reinforcement and development efforts. In this case, the pesantren provide knowledge, training, and guidance to santri about various matters relating to the creative economy, such as batik craft training. They offer the students the opportunity trough internship in cooperatives and pesantren, creative economy workshops, and comparative studies of economic governance creative to various pesantren. In order to maximize this effort, Miftahul Ulum Pesantren applies a cross-departmental vocational learning system. Some of them are majoring in fashion, culinary, and informatics engineering. Second, practical approach, the santripreneur agenda in the Miftahul Ulum Pesantren is carried out in various forms of economic activities that come in direct contact with the world of entrepreneurship and business. In general, the practical approach here relies on economic activities such as the Al-Iktisab kopontren supermarket, and the sharia cooperative, BMT al-Ikhtisab which provides savings and loan services and sharia-based investment.

Seeing the large potential of the role and strategic functions of the pesantren's creative economy, especially in the development sector and sustainable economic development based on local wisdom, it is necessary for pesantren to continue to strengthen themselves, maximize their naturalsocial potential to build a strong local economy and independent. The most important thing of all is the involvement of all parties and stakeholders to continue to encourage and pay considerable attention to the existence of pesantren. That the creative economic activities of pesantren in the future need to be balanced and supported by an economic political policy that truly establishes harmony with the strengthening and development of pesantren economic development going forward. 


\section{References}

Abdullah, Irwan, dkk (ed.). (2008). Agama dan Kearifan Lokal dalam Tantangan Global. Yogyakarta: Pustaka Pelajar.

Abdullah, Said. (2007). Pesantren, Jati Diri dan Pencerahan Masyarakat,

Cet. I. Sumenep: Said Abdullah Istitute Publishing.

Afidah, Siti. (2018). Santripreneurship Kaum Pesantren, Studi pada Pesantren Santripreneur Tegalrejo Magelang. Tesis UIN Walisongo.

Arafah, N. (2002). Pengetahuan Lokal Suku Moronene dalam Sistem

Pertanian di Sulawesi Tenggara. Program Pascasarjana Institut

Pertanian Bogor.

Bawono, Anton (2018). Creative Economic Development of Pesantren.

Shirkah; Journal of Economics and Business, 3 (1).Departemen

Pendidikan dan Kebudayaan. (1999).

Hidayati, Tatik. (2009). "Perempuan Madura Antara Tradisi dan Industrialisasi”, Jurnal Karsa, vol. xvi, no. 2.

Jafar. (2017). "Solidaritas Imigran Madura di Perantauan Desa Jemparing Kecamatan Longikis Kabupaten Paser. eJournal Sosiatri-Sosiologi, Vol. 5, No. 1.

Kemenperin. (2015) Santripreneur Wujudkan Ekonomi Berbasis Syariah, http://www.kemenperin.go.id/artikel/18398/SantripreneurWujudkan-Ekonomi-Berbasis-Syariah, diakses pada 21 April 2019 (19: 55)

Leksono, Afif dan Purbayu Budi Santosa. (2014). Faktor-Faktor Yang Mempengaruhi Pendapatan Industri Kreatif Di Indonesia (Tahun 2002 - 2008). Journal of economic, Vol. 3 (1).

Lucy, Bunda. (2009). Mendidik Sesuai dengan Minat dan Bakat Anak. Jakarta: Pustaka.

Maksum, Toha dan Muh Barid Nizaruddin Wajdi. (2018). "Pengembangan

Kemandirian Pesantren melalui Program Santripreneur". Engagement; 
Jurnal Pengabdian pada Masyarakat, Vol. II, (2).

Nur Hayati, Beti dan Muhammad Arif Fahrudin Alfana. (2016). "Kebijakan Kependudukan di Kabupaten Sleman Pasca Berakhirnya MDGS”. Jurnal Kajian Ilmu Administrasi Negara, Vol.4 (2).

Sartini. (2004). "Menggali Kearifan Lokal Nusantara Sebuah Kajian Filsafat". Jurnal Filsafat, Vol. 37 (2) .

Sulistyo, Budi, dkk. (2010). MDGs Sebentar Lagi. Jakarta: Penerbit Buku Kompas.

Susanto, Edi. (2007). "Revitalisasi Nilai Luhur Tradisi Lokal Madura". Jurnal Karsa, Vol. xii (2). 


\section{Shirkah Author Guidelines}

Shirkah currently offers two routes to submit manuscripts. We highly recommend to submit the articles which are made using OJS (Open Journal System). Feel free register as author soon through visiting http:// shirkah.or.id/index.php/home/user/register. The authors may directly send their manuscripts, along with their resume, to shirkahiainsurakarta@ gmail.com. Please prepare your manuscripts, using following guidelines:

1. Manuscript must be written in English. Submitted articles should not have been published or be under review for publication with another journal.

2. Manuscript's length is about $15-20$ pages, typed in one-half spaced on A4-paper size.

3. Manuscript must include an $150-200$ word abstract and keywords.

4. Manuscript must be arranged as follows: Title, Name of Author, E-mail address, Abstract, Keywords, Introduction (including method if any), Discussion, Conclusion, References.

5. Manuscript's titles not more than ten words.

6. Manuscript must be submitted in Microsoft Word or RTF.

7. Arabic words should be transliterated according to the style of International Journal of Middle Eastern Studies.

8. Manuscript references are preferably derived from the up-to-date references.

9. The author's resume should be submitted separately, consisting of at least full name, institutional address, phone number, areas of studies, and recent publications (if any).

10. Shirkab use APA Style 6th edition (2010) as reference format writing. We suggest the use of a reference manager software such as Mendeley, Zotero, and Endnote at templating the citation style. APA Style to be used is as follows: 


\section{Book with single author}

Swann, G. M. Peter. (2014). The Economics of Innovation an Introduction. Cheltenhum \& Northampton: Edward Elgar.

in-text citation: (Swann, 2014)

\section{Articles in reference books}

Alatas, S. F. (2006). Islam and the Science of Economics in Abu Rabi', I.M. The Blackwell Companion to Contemporary Islamic Thought. USA: Willey-Blackwell (pp. 587-606).

in text citation: (Alatas, 2006)

\section{E-Book}

Hackett, Rosalind (2007). "Religous Dimentions of War and Peace: Introduction.” Dalam Gerrie ter Haar dan Yoshio Tsuruoka (Ed.), Religion and Society: An Agenda for the 21st Century (h. 3-6). Retrieved from http:// brill.nl.

in text citation: (Hackett, 2006)

\section{Master's thesis, from a commercial database}

McNieI, D. S. (2006). Meaning through narrative: A personal narrative discussing growing up with an alcoholic mother (Master's thesis). Available from ProQuest Dissertations and Theses database. (UMI No. 1434728)

in text citation: (Mc Niel, 2006)

\section{Doctoral dissertation, from an institutional database}

Adams, R. J. (1973). Building a foundation for evaluation of instruction in higher education and continuing education (Doctoral dissertation). Retrieved from http://www.ohiolink.edu/etd/

in text citation: (Adams, 1973) 


\section{Doctoral dissertation, from the web}

Bruckman, A. (1997). MOOSE Crossing: Construction, community, and learning in a networked virtual world for kids (Doctoral dissertation, Massachusetts Institute of Technology). Retrieved from http:/www-static. cc.gatech.edu/--asb/thesis/

in text citation: (Bruckman, 1997)

\section{Journal article with No DOI}

Bourkhis, K., and Nabi, M. S. (2013). Islamic and conventional banks' soundness during the 2007-2008 financial crisis. Journal Metrics, 22(2), 68-77.

in-text citation: (Bourkhis \& Nabi, 2013).

\section{Journal article with DOI}

Ichwan, M. (2012). The Local Politics Of Orthodoxy: The Majelis Ulama Indonesia in the Post-New Order Banten. Journal Of Indonesian Islam, 6(1), 166-194. doi:http://dx.doi.org/10.15642/JIIS.2012.6.1.166-194

In text citation : (Ichwan, 2012)

\section{Abstract as citation}

Hasan, N. (2012). Islamist Party, Electoral Politics And Da'wah Mobilization Among Youth : The Prosperous Justice Party (PKS) in Indonesia. Journal of Indonesian Islam, 6(1), 17-47. Abstract from http:// jiis.uinsby.ac.id/index.php/jiis/article/view/97

in text citation : (Hasan, 2012)

\section{Mass media article}

Sahal, Akhmad (2014, March 2). Kiai Sahal dan Realisme Fikih.Tempo Magazine, p. 120.

in text citation : (Sahal, 2014) 


\section{Research report}

Fisher, B. S., Cullen, F. T., \& Turner, M. G. (2000). The Sexual Victimization of College Women. Research Report.

in text citation : (Fisher, Cullen, Turner, 2000)

\section{Monograph}

Routray, Bibhu Prasad (2013), National Security Decision-Making in India (RSIS Monograph No. 27). Singapura: Rajaratnam School of International Studies.

in text citation : (Routray, 2013)

\section{Proceeding article}

Sudibyakto, Hizbaron, D.R., \& Jati, R (Ed.) (2009), Proceeding International Seminar Disaster Theory, Research and Policy. International seminar held by Sekolah Pascasarjana, Universitas Gajahmada, Yogyakarta, 8-9 Desember 2009.

in text citation : (sudibyakto and Jati, 2009)

\section{Paper conference/seminar/symposium}

Janutama, Herman Sinung (2011). "Kraton dan Hubungan Antar Agama." Paper presented in Seminar Kraton dan Panatagama held by Center for the Study of Islam and Social Transformation (CISForm), Yogyakarta, 17 November.

in text citation :(Janutama, 2011)

\section{Online article in web}

Shiva, (2006, February). Bioethics: A Third World Issue. Native-web. Diperoleh dari http://www.nativeweb.org/ pages/legal/shiva.html

in text citation : (Shiva, 2006) 


\section{Online research report}

Kessy, S. S. A., \& Urio, F M. (2006). The contribution of microfinance institutions to poverty reduction in Tanzania (Research Report No. 06.3). Retrieved from Research on Poverty Alleviation website: http://www. repoa.or.tz /documents_storage/Publications/Reports/06.3_Kessy_and_ Urio.pcif

in text citation : (kessy and urion, 2006)

\section{Holy book}

Qur an, $2(25)$

In text citation : (Q. al-Baqarah 2:25).

\section{Encyclopaedia}

Graycar, Adam (1992). Social Welfare Policy. Dalam Mary Hawkesworth dan Maurice Kogan (Ed.), Encyclopedia of Government and Politics (Vol. 1). London: Routledge.

in text citation : (Graycar, 1992)

\section{Interview}

Sultan Hamengkubuwono X (interview, 2011, April 19)

in text citation: (Hamengkubuwono, 2011)

\section{Documentary film}

Steijlen, Fridus (2008). A Day in the Life of Indonesia [documentary film, 58 minutes]. Leiden: KITLV Press.

in text citation : (Steijlen, 2008) 
Vol. 4 No. 2, May - August 2019 